\title{
USING MULTI-SCALE SPATIAL AND STATISTICAL ANALYSIS TO ASSESS THE EFFECTS OF BROWNFIELD REDEVELOPMENT ON SURROUNDING RESIDENTIAL PROPERTY VALUES IN MILWAUKEE COUNTY, USA
}

\author{
Wenjie SUN, Brendon JONES
}

\begin{abstract}
Brownfield redevelopment has gained support in the U.S. as an essential ingredient of urban revitalization. Assessing the effects of such projects is important as government budgets tighten recently. Through multi-scale spatial and statistical analysis, this study shows the spatial patterns of residential property values and their changes, and investigates linkages to the presence of different types and sizes of nearby brownfield redevelopment projects, as opposed to neighborhood demographics and property characteristics. While the results of this study suggest brownfield redevelopment does play a positive role on the surrounding residential property values in general, there are quite different statistical significances found at the two levels of analysis and the type of redevelopment found to determine the direction of this effect.
\end{abstract}

\section{Shrnutí}

\section{Využití vícerozměrné prostorové a statistické analýzy pro hodnocení efektu revitalizace brownfields na cenu okolních rezidenčních nemovitostí v okrese Milwaukee, USA}

Revitalizace brownfields získala v USA podporu jako podstatná součást revitalizace měst. Hodnocení efektů takovýchto projekti̊ je důležité, nebot státní rozpočty se v poslední době stále snižují. Tato studie uvádí pomocí vícerozměrné prostorové a statistické analýzy prostorové změny cen residenčních nemovitostí a studuje jejich závislost na projektech revitalizace brownfields různých typü a velikostí realizovaných $v$ jejich blizkosti. Přestože výsledky studie nasvědčují, že revitalizace brownfields $v$ blízkém okolí má na cenu rezidenčních nemovitostí obecně pozitivní vliv, při dvouúrovñové analýze bylo zjištěno, že existuji zcela odlišné statistické významnosti závislé na typu revitalizace, který směr tohoto efektu určuje.

Keywords: brownfield redevelopment, spatial analysis, statistical analysis, residential property values, Milwaukee County, USA

\section{Introduction}

The creation of the EPA's (Environmental Protection Agency) brownfield programme in 1995 changed the views of people looking at contaminated properties in the United States. Brownfields are officially defined as "real property, the expansion, redevelopment, or reuse of which may be complicated by the presence or potential presence of a hazardous substance, pollutant, or contaminant". The U.S. Government Accountability Office (2000) has estimated there may be between 130,000 and 450,000 brownfields throughout the United States. Municipalities and neighbourhoods share similar concerns about fallow property, the only differences are the risks assessed by each investor
(Ellerbusch, 2006). One observation by Greenberg (1998) states that "idle sites have led to decay; the decay has lowered neighbouring property values, which has led to more property abandonment, or in other words the neighbourhood equivalent of cancer". Having abandoned properties in a neighbourhood lowers property values along with other negative consequences. "Abandoned sites have been used for illicit activities; have increased crime that has resulted in more blight and therefore more decay" (Greenberg and Schneider, 1996). Brownfield properties are also subject to more attention from local police and fire departments as maintenance efforts are required. By redeveloping brownfield sites, we can make them more productive and make cities safer. 
The rewards of brownfield redevelopment are vast and have the capability to last well into the future environmentally, socially, and economically. "Possible benefits from brownfield redevelopment include revitalization of inner city neighbourhoods through job and tax revenue creation, control of green field encroachment and urban sprawl, and the use of existing infrastructure" (Amekudzi, 2003). With the ever-increasing population of the United States, it becomes more and more necessary to use land to its fullest potential. This equates to "recycling" properties and not contributing to urban sprawl. Brownfield redevelopment is part of "smart growth" principles. Smart growth principles involve using land in more efficient ways. This entails mixed land use, including constructing commercial and residential buildings together. Mixed land use makes cities more centralized and cuts down on transportation and other costs.

There is an increasing but still limited literature about brownfield redevelopment and about the benefits they create. One way to measure the economic benefit of brownfield redevelopment is to calculate the value of redeveloped land parcels and the associated increase in direct property taxes (De Sousa, 2005). Another way is to gauge the spillover or ripple effect on the surrounding community by measuring the impact of brownfield redevelopment on neighbouring property values (Simons, 2005; Simons and Saginor, 2006). Simons (2005) looks at whether existing brownfield sites have a significant effect on nearby property values and how this effect changes after the sites are redeveloped. While comparatively earlier studies have focused on commercial and industrial properties, more recent ones have started to investigate surrounding residential properties, and in general brownfields have been shown to lower the value of surrounding residential property, whereas redevelopment allows it to increase (Kaufman and Cloutier, 2006; Simons and Saginor, 2006). We know that brownfield redevelopments affect the values of surrounding properties, but to what degree? People are still unfamiliar with the benefits that brownfields have on communities, especially on residential and commercial properties. When people are unfamiliar with the brownfields, it is difficult to gain and attract funding. "The main barrier to brownfield redevelopment constantly shown in literature is the lack of funds. A significant barrier to attracting funds is the lack of specific information about the benefits that brownfield projects create" (De Sousa et al., 2009). Spatial analysis and mapping provide an effective way of visually showing the consequences of redeveloping brownfields. This study will hopefully give municipalities, private investors, and other forms of government the necessary tools to make informed decisions about investing in brownfields.
Past literature illustrates a considerable gap when it comes to the use of Geographic Information Systems (GIS) to study and analyze brownfield developments. Many earlier research projects have focused heavily on statistical and survey methods to study the effects of brownfields and their redevelopment. While the statistical analysis is a powerful and widely accepted way of quantitatively determining the impacts of brownfields and their redevelopment, it may seem perplexing to the average person by itself. Survey methods may seem to be an intuitive and direct way of quantitatively and qualitatively measuring effects, but the efforts to design, test, and administer a survey are far less cost effective and the response rate and representativeness of the survey results cannot be guaranteed. Significantly fewer studies have used GIS to its fullest potential concerning urban planning. "A review of all articles appearing in the Journal of Urban History and the Journal of Planning History from January 2002 to December 2009 revealed that while maps are frequently incorporated, maps created with GIS are rare" (Hillier, 2010). GIS allows users to incorporate multiple attributes at once, to be able to discern spatial patterns and infer underlying processes. Users can also map a wide variety of data, even attributes that seem incomparable juxtaposed, e.g. coffee shops and historic battlegrounds (Lejano, 2008). Seemingly the general public, certainly municipality and other governmental employees, should be able to identify, through maps created with GIS, the effects of brownfield redevelopment in a more effective and straightforward way. Digital data are also widely available for GIS mapping and analysis through reputable sources. The U.S Census Bureau, the U.S Environmental Protection Agency, State Departments of Natural Resources, and other government agencies have data readily available for download regarding brownfields and sociodemographic attributes.

While GIS may be an important tool in studying the redevelopment of brownfields, it is imperative not to get so focused on mapping that users forget about other applicable factors. "One of the faults of GIS is that users may fall into a state of hypostatization - taking the concepts they see through mapping and involuntarily believing them to be the truth" (Lejano, 2008). Users of GIS may read too much into the maps they create or misinterpret them. GIS analysis should never be a substitute for real "on the ground" analysis. There are factors that may not appear through GIS that would be ignored if the ground analysis of a site was not performed. GIS should be used as a complement to field analysis, as a useful tool to identify spatial patterns and seek possible spatial explanations. 
This study has the potential to contribute significantly to the brownfield community. Outside of the environmental field, few people are familiar with brownfields. This study will investigate spatially the benefits brownfield redevelopment projects have on local neighbourhoods at multiple levels of analysis. If this study can show that surrounding property values will increase as a result of redevelopment projects, funding will be easier to generate for future projects. Communities and residents near a site will be more willing to help and join together on a project they know will impact them positively as well. This study may also be used as a guide for the selection and prioritization of future redevelopment projects. Through GIS we can target individual neighbourhood factors (e.g. distance to parks, income and unemployment) and determine what types of redevelopment increase property values the most and thus promise a better return on investment.

\section{Methodology}

To address the question of what effects brownfield redevelopment projects cast on surrounding residential property values in Milwaukee County, GIS and statistical analysis were employed in this research. A variety of data from different sources was used and analyzed through the ArcGIS and SPSS software. This

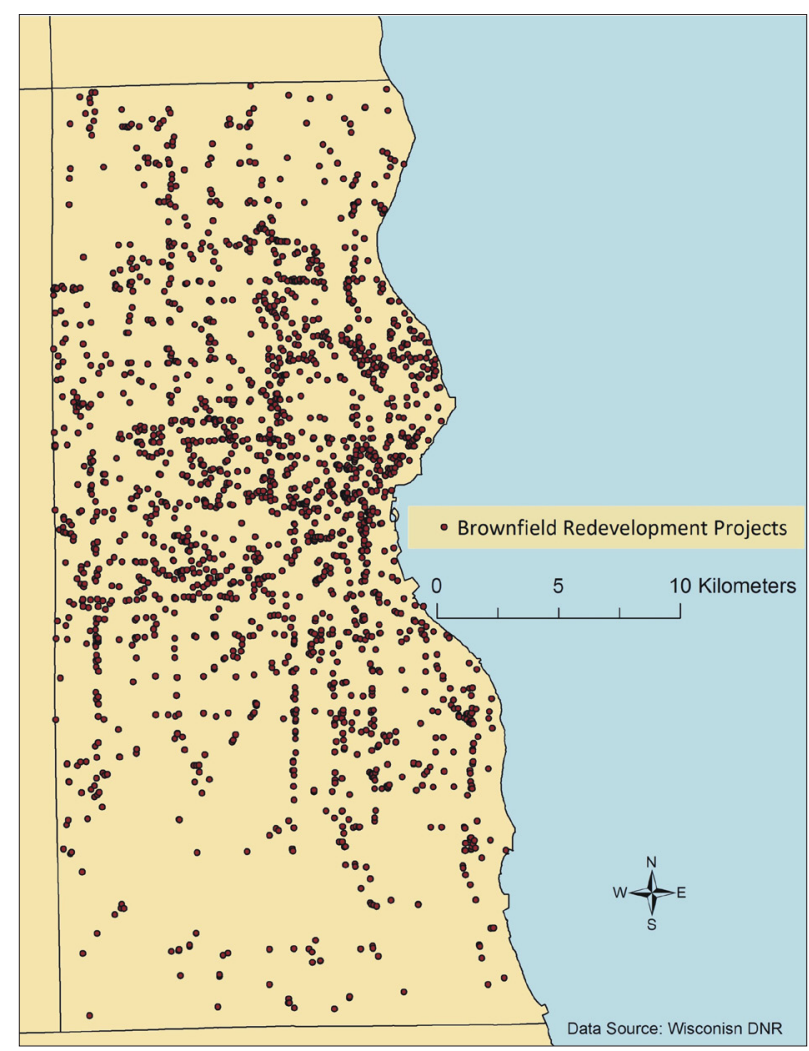

Fig. 1: Map of Milwaukee County showing all brownfield redevelopment projects from 1996 to 2004 Source: Wisconsin DNR research will hopefully help give guidance and expand the state and nation's brownfield programme through increased knowledge and funding.

\subsection{Study Area}

This research study focuses on Milwaukee County, located north of Chicago and on the west coast of Lake Michigan. Milwaukee, like many other cities in the Midwest, was a 'Mecca' for industries during the early 1900s. As years went by and the economic structure evolved, industrial companies moved away or went out of business, leaving behind numerous abandoned buildings and properties. Thus, Milwaukee County, particularly the metropolitan area, presents itself as a relevant venue for this study due to its large amount of brownfield sites and redevelopment projects (Fig. 1), according to the Wisconsin State Department of Natural Resources (DNR).

\subsection{Data Acquisition}

For this project, brownfield redevelopment projects with some public funding completed between 1997 and 2003 in Milwaukee County were used to examine their effects on surrounding residential property values. These data were gathered through the Department of City Development and the Milwaukee property files database. The data were given in a GIS compatible, shapefile format. The shapefile contains

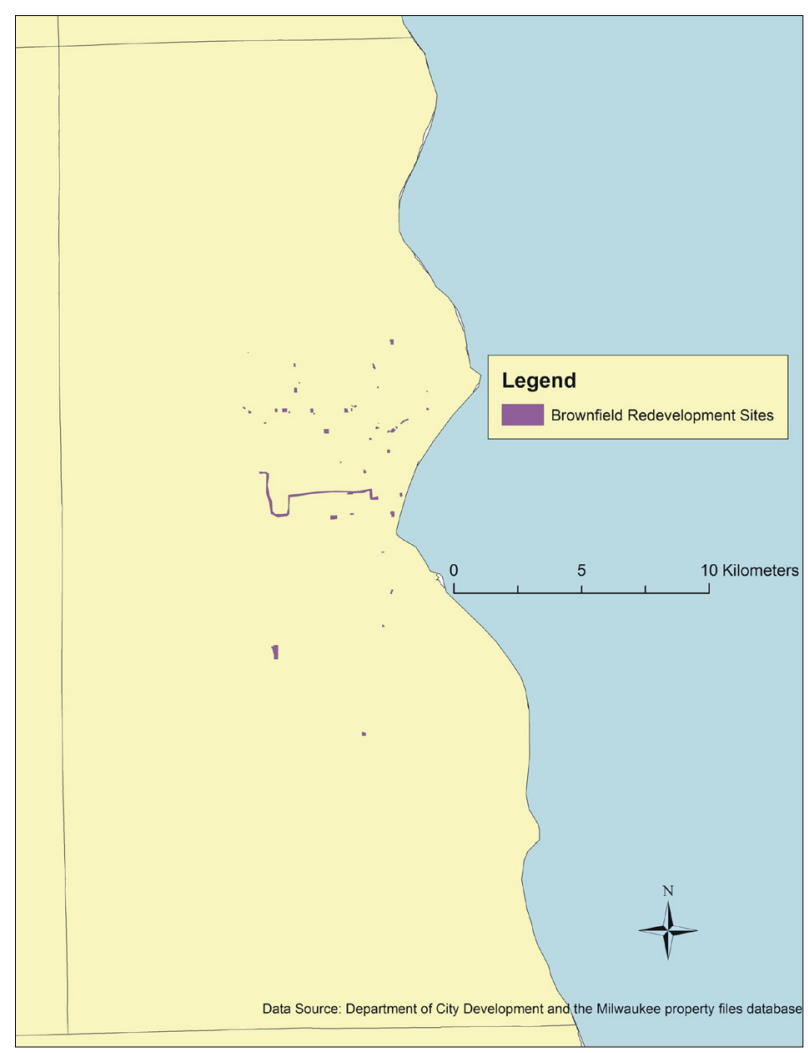

Fig. 2: Location of 45 brownfield redevelopment projects completed between 1997 and 2003 in Milwaukee County Source: Department of Milwaukee City Development 
a total of 45 varying sized polygons (Fig. 2). Each polygon contains a list of different attributes such as redevelopment cost, start date, and the building area.

Housing sales transaction data (from local Multiple Listing Service offices) located near brownfield redevelopment projects in Milwaukee County from 1996 and 2004 were utilized as the "before" and "after" measurements of residential property values. These point data were also given in shapefile format accessible in ArcGIS. The real estate transaction data contain a variety of attributes with each property, including selling price, and a detailed array of physical properties of the house such as square footage, number of bedrooms, year built, etc.

Population Census data from the U.S Census Bureau were acquired at the block group level for Milwaukee County. Within the county of Milwaukee there are 881 individual block groups. Data from the census year 2000 was downloaded from the U.S Census Bureau website. For our study we gathered a selection of demographic, social and economic variables. They included median household income, unemployment rate, poverty rate, education attainment, ethnicity, and population density. Data from the 2000 census were used mainly because they fit the time frame of both brownfield redevelopment and real estate transaction data, as it is the middle year.

Other complementary data were also acquired from the Wisconsin DNR and the National Land Cover Database. Every brownfield redevelopment-related activity in the state of Wisconsin from 1980 to present was included in the Wisconsin DNR database. Land Cover data were used to show the change in land cover within the county of Milwaukee from 1992 to 2001.

In order to keep all the spatial data layers lined up with one another before analysis, each was projected to the UTM Zone $16 \mathrm{~N}$. This projection best fits the study area of Milwaukee County and minimizes distortion for distance calculations.

\subsection{Field Visits}

The study started with field tours of several brownfield redevelopment sites, representing each of the different redevelopment types (residential, commercial, industrial, etc.). These tours were useful to get a ground level breakdown of the different sites and a chance to interview local inhabitants about the area and redevelopment project. The field visits and interviews are something that cannot be duplicated in a lab and are invaluable in this research by offering a fundamental contextual understanding of what makes a brownfield redevelopment project successful.
For example, Fig. 3 shows a former brownfield site redeveloped into a condominium.

\subsection{Spatial Analysis}

The spatial data were analyzed through the ESRI ArcGIS software. Once the data were added into the map, the first step was to spatially join the housing point data to the census block groups. When this was done, the next step was to summarize the housing data by block groups so that we could average the selling price at a block group level. After the 1996 data were computed, the same procedures were followed for the 2004 housing transaction data. Following the computation of the average selling price for 1996 nd 2004 by the block group, a percent change was calculated. At this stage, inflation was accounted

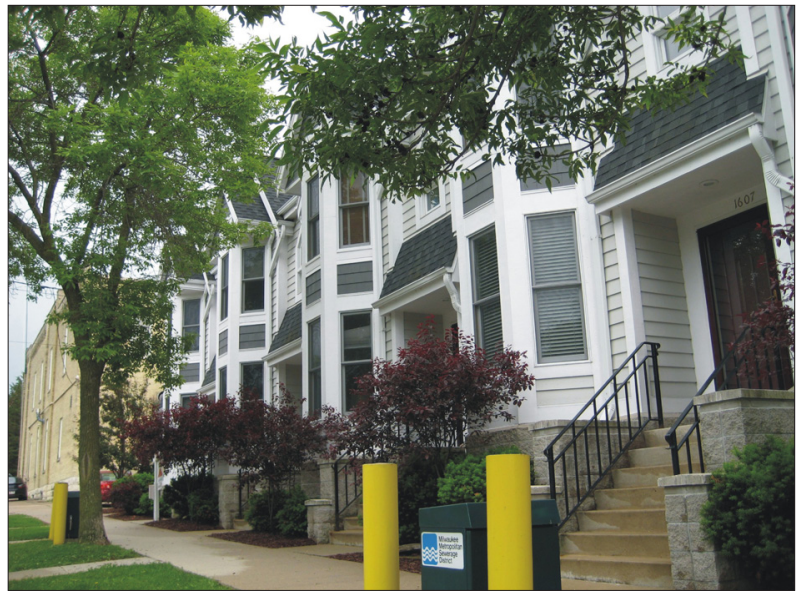

Fig. 3: Photo of a residential brownfield redevelopment project (Photo: Brendon Jones)

and adjusted for the average selling prices by block group. The inflation rate was taken from the Bureau of Labour Statistics. Once the percent property value change from 1996 to 2004 was plotted on a map of Milwaukee County, there appeared to be some clustering of high values of percent change. This could not be certain, however, because any map can appear to have clustering by simply adjusting the classification scheme. In order to explore this spatial pattern further, three questions were posed in sequence:

1. Is there any spatial clustering of percent housing price change by block group?

2. If there is clustering, is it clustering of low or high values?

3. If there is clustering of high values, where are the clusters (hot spots)?

In order to answer the first question, a spatial statistics tool in ArcGIS called Global Moran's I was run. The Global Moran's I statistic measures spatial autocorrelation based on feature locations and attribute values. Given a set of features and an associated attribute, the spatial autocorrelation tool 
evaluates whether the pattern expressed is clustered, dispersed, or random. When the z-score or p-value indicates statistical significance, a positive Moran's I index value indicates tendency toward clustering, while a negative Moran's I index value indicates tendency toward dispersion.

When it was determined there was a spatial clustering, the next step was to ask whether there are high or low spatial clustering values? In order to answer this question another tool in ArcGIS called General $\mathrm{G}$ was run to investigate the values. The General $\mathrm{G}$ tool measures concentrations of high or low values for a study area. A high index value as a result of the General $\mathrm{G}$ tool indicates clusters of high values. A low index value indicates clusters of low values. Like the Global Moran's I, the z-score or p-value determines how statistically significant the results are.

The final question was to see where the clusters of high values are located within the study area. The final tool to run within ArcGIS is called the Hot Spot Analysis tool. Unlike the previous tools that give a graph and a statistic, the hot spot analysis tool will show on a map the clusters of high values, also known as the hot spots. This tool works by looking at each feature in relationship with its neighbouring features. If a feature's value is high, and the values for its neighbouring features are also high, it is referred to as a hot spot. Once the hot spots were shown on the map, the next step would be to overlay this map with the redeveloped brownfield polygons to see if there is a spatial correlation.

\subsection{Statistical Analysis}

For the statistical portion of this study, both Ordinary Least Squares Regression (OLS) and Geographical Weighted Regression (GWR) were performed (see e.g. Legg, Bowe, 2009), first at the block group level. Regression is used to evaluate relationships between two or more variables. OLS creates a single regression equation for all features (block groups). GWR differs by creating a regression equation to fit each feature (block group) in a study area. The dependent variable for the regression models was the percent housing price change from 1996 to 2004. A variety of independent variables was used, broken down into three categories:

1. Aggregated housing characteristics: Average house age and average number of bedrooms per house by block group;

2. Demographics: Population density, percentage African American, percentage Hispanic, median household income, percentage below poverty line, percentage below high school education, and unemployment rate; and

3. Near-by brownfield characteristics: Distance to nearest brownfield redevelopment site, size of brownfield redevelopment, and the type of brownfield redevelopment (residential, commercial, industrial - coded as dummy variables).

The study started by investigating possible contributing factors of housing price change at the block group level, particularly along the lines of neighbourhood demographics and nearby brownfield characteristics. A SPSS step-wise regression was used to determine the most statistically significant independent variables for the study. However, the individual house or property level may actually represent a more natural scale of analysis, given that many meaningful effects of brownfields and their redevelopment on residential property value ultimately operate at this level. Therefore, regression analyses (OLS and GWR) were then conducted at the property level in order to gain more specific insight at a finer spatial scale. For 1996, each house's selling price was used as the dependent variable, and the total number of bedrooms per house, the distance to the closest brownfield, the age of the house, the square footage of the house, and other location factors (distances to water, rail, roads, etc.) were incorporated as independent variables. For 2004, each house's selling price was used as the dependent variable, and the same set of variables as in the 1996 model, plus the redevelopment type (recoded as dummy variables) and the investment cost of the closest brownfield redevelopment, were incorporated as independent variables.

\section{Results}

\subsection{Exploratory Mapping}

According to the data that were acquired from the Wisconsin DNR, brownfields started to be redeveloped in Wisconsin from 1980 and have continued to the present day. It was determined that between 1996 and 2004 was a time period of increased brownfield development (Fig. 1).

When looking at the land cover change map between the years of 1992 and 2001 (Fig. 4), there are certain areas of change in Milwaukee County. These changes mostly tend to be found in the outer edges of the county but not in the urban core. Most changes occurred in agriculture, going from agriculture to forest, agriculture to urban, etc.

\subsection{Spatial Analysis}

The results of the Spatial Autocorrelation (Moran's I) analysis showed there was a statistically significant spatial clustering of block group level percent housing price change 1996 to 2004, and the confidence level was very high - meaning that users can be sure this clustering is not a result of random change. 
Based on the results from the General G analysis, there was spatial clustering of high values of percent property value change. Much like the previous step, the results also carried a high level of statistical significance and confidence level.

The hot spot analysis (Fig. 5) did indeed show areas of high values of percent property value change clustering in the north of the city centre. In other words, the north of the urban core area has seen a concentration of greater property value increases from 1996 to 2004. By performing two simple 'select by location' queries in ArcMap, we find that 73 out of 73 (100\%) identified hotspots of housing price changes are within one mile $(1.6 \mathrm{~km})$ of the 45 brownfield redevelopment sites, whereas only 201 out of 398 (51\%) of the non-hotspots are within the same distance. Figure 6 shows a zoomedin view on these hot spots overlaid with redeveloped brownfield sites.

\subsection{Statistical Analysis}

For the statistical analysis, four sets of regressions were run, two at the block group level and two at the property level. The results generated from both the OLS and GWR regression at the block group level did not seem to offer a worthwhile explanation (i.e., a low $\mathrm{R} 2$ value) for the percent change in housing values from 1996 to 2004. The brownfield redevelopmentrelated independent variables were not found to

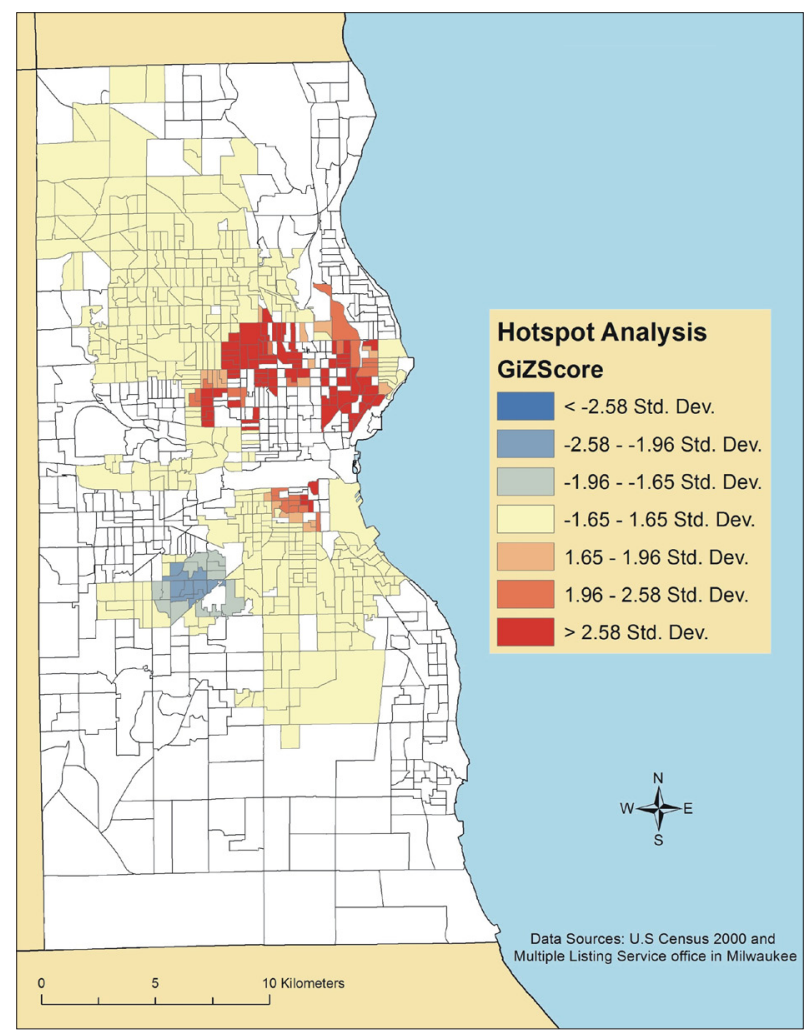

Fig. 5: Map of Milwaukee County hot spot analysis of percent housing price change 1996-2004 by block group be as statistically significant as the neighbourhood demographics and aggregated physical attributes of the houses.

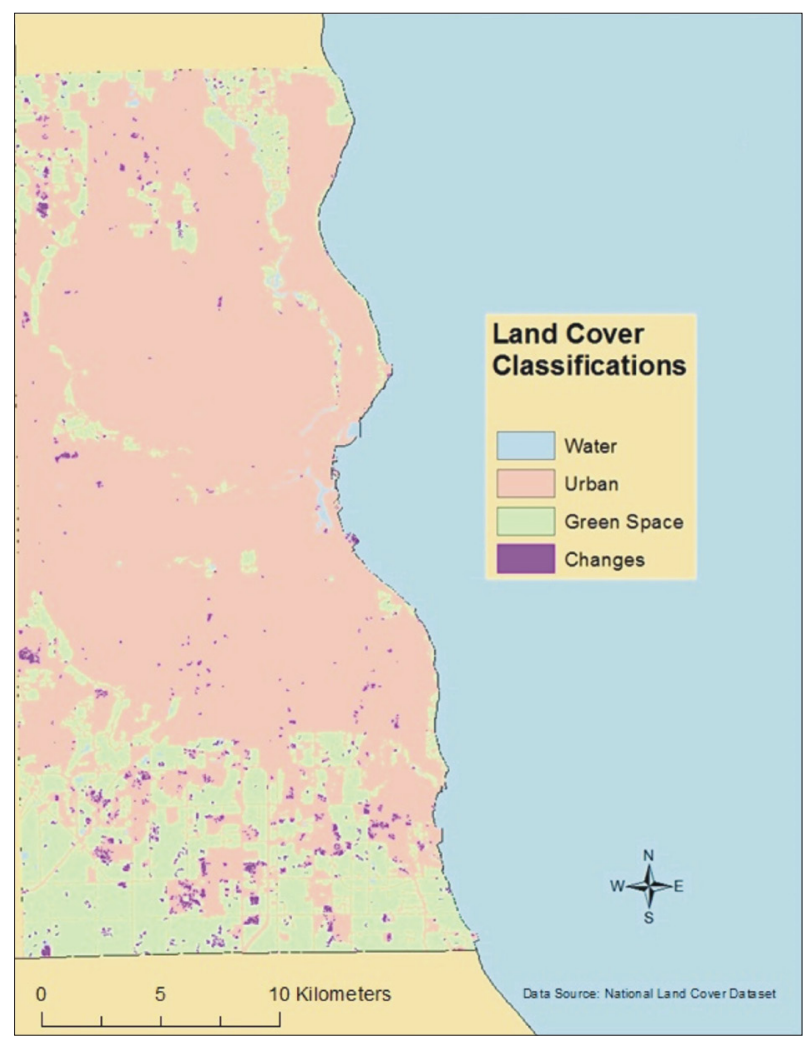

Fig. 4: Land cover change in Milwaukee County from 1992 to 2001

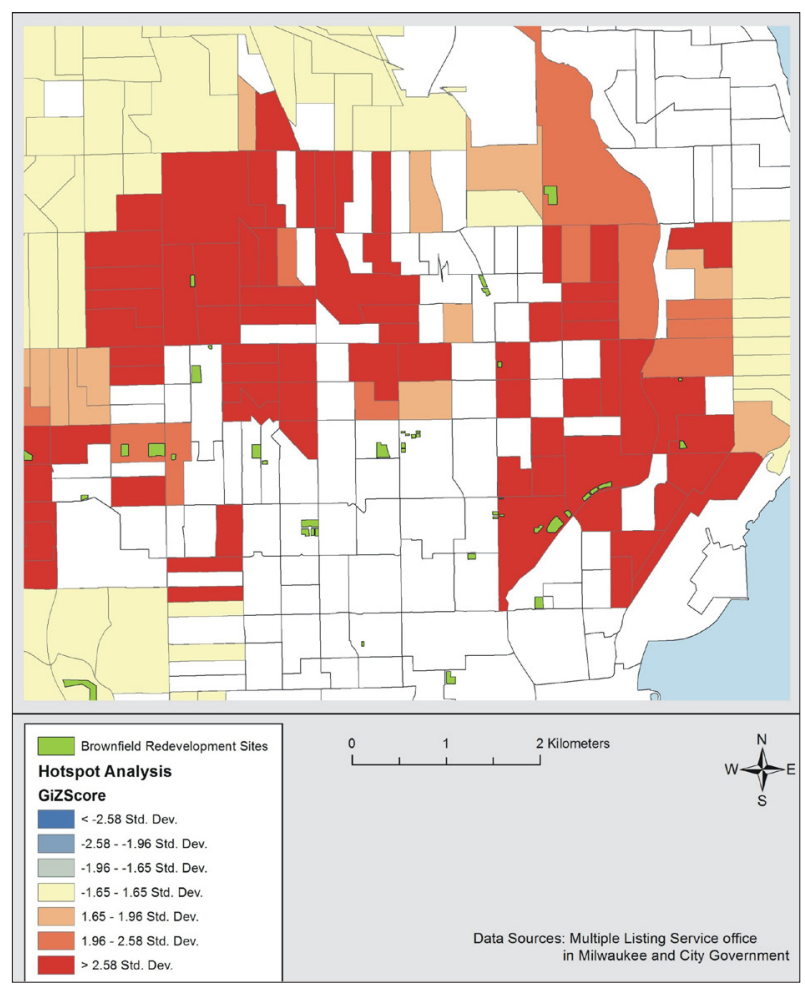

Fig. 6: Zoomed-in map of Milwaukee County hot spot analysis of percent housing price change 1996-2004 by block group with brownfield redevelopment sites 
Property level OLS and GWR regressions were able to achieve a much more successful and promising explanation of property values with significantly higher $\mathrm{R} 2$ and reasonably randomly distributed residuals over the study area: refer to Tables 1-3 for the detailed OLS step-wise regression results of 1996 and 2004. In 1996, square footage, age, number of bedrooms, distance to water, and distance to rail, were found to have a statistically significant impact on the values of individual properties, with an overall R2 of 0.626 for the model. In 2004, a few more variables were found statistically significant, including the closest brownfield redeveloped into residential use (positive effect), commercial use (negative effect), redevelopment cost (negative effect), distance to closest brownfield site (positive effect), distance to road, and closest brownfield redeveloped into industrial use (negative effect). The regression model achieved an R2 of 0.651 . Figure 7 shows the range and distribution of local $\mathrm{R} 2$ values of the 2004 property level GWR fitting, which seemed to suggest that there were better fits of the model north of the city centre.

\section{Discussion and Conclusion}

\subsection{Summary of Main Findings}

The results of the spatial analysis at block group level do seem to suggest that brownfield redevelopment projects play a positive role on surrounding property values. When looking at Fig. 6 we see that 42 out of the 45 total brownfield redevelopment projects are within one mile of the clusters of high percentage increase in real estate selling price between 1996 and 2004. 37 of 45 are within one half-mile $(0.8 \mathrm{~km})$ of the hotspots, and 28 are within one quarter-mile. We also find that $100 \%$ of the identified hotspots of housing price changes (increase)

\begin{tabular}{|l|c|c|c|c|c|}
\hline \multirow{2}{*}{$\begin{array}{c}\text { Model Independent } \\
\text { Variables }\end{array}$} & \multicolumn{2}{|c|}{ Unstandardized Coefficients } & $\begin{array}{c}\text { Standardized } \\
\text { Coefficients Beta }\end{array}$ & t & Sig. \\
\cline { 2 - 5 } & $\mathrm{B}$ & Std. Error & & 13.388 & .000 \\
\hline (Constant) & $67,058.351$ & $5,008.749$ & & 37.319 & .000 \\
\hline SqFootage & 77.705 & 2.082 & -.834 & -19.670 & .000 \\
\hline HouseAge96 & -932.960 & 47.430 & -.398 & -5.385 & .000 \\
\hline \# of bdrm & $-7,520.305$ & $1,396.521$ & -.117 & -6.592 & .000 \\
\hline DistToWater & -2.040 & .310 & -.135 & 4.130 & .000 \\
\hline
\end{tabular}

Tab. 1: Property Level OLS Regression Coefficients 1996

Note: Dependent Variable: Inflation Adjusted Sold Price in 1996

\begin{tabular}{|l|r|r|r|r|r|}
\hline \multirow{2}{*}{$\begin{array}{c}\text { Model Independent } \\
\text { Variables }\end{array}$} & \multicolumn{2}{|c|}{ Unstandardized Coefficients } & $\begin{array}{c}\text { Standardized } \\
\text { Coefficients Beta }\end{array}$ & t & Sig. \\
\cline { 2 - 5 } & \multicolumn{1}{c|}{$\mathrm{B}$} & Std. Error & & 9.779 & .000 \\
\hline (Constant) & $92,316.282$ & $9,440.241$ & & 43.719 & .000 \\
\hline SqFootage & 129.425 & 2.960 & -.763 & -14.811 & .000 \\
\hline RouseAge04 & -907.548 & 61.276 & -.278 & 3.738 & .000 \\
\hline \# of bdrm & $24,979.900$ & $6,682.792$ & .124 & -9.408 & .000 \\
\hline RedevCom & $-16,133.914$ & $1,714.935$ & -.159 & -7.531 & .000 \\
\hline RedevCost & $-39,332.022$ & $5,222.553$ & -.249 & -7.012 & .000 \\
\hline DistToRail & -.001 & .000 & -.154 & 8.848 & .000 \\
\hline DistToWater & 3.945 & .446 & .158 & -9.293 & .000 \\
\hline DistToRedev & -4.016 & .432 & -.170 & 6.334 & .000 \\
\hline DistToRoad & 1.430 & .226 & .129 & -5.055 & .000 \\
\hline RedevInd & -3.749 & .742 & -.084 & -2.640 & .008 \\
\hline
\end{tabular}

Tab. 2: Property Level OLS Regression Coefficients 2004

Note: Dependent Variable: Sold Price in 2004

\begin{tabular}{|c|c|c|c|c|}
\hline Model & $\mathbf{R}$ & R Square & Adjusted R Square & Std. Error of the Estimate \\
\hline 1996 & .791 & .626 & .625 & $30,345.243$ \\
\hline 2004 & .807 & .651 & .649 & $46,777.342$ \\
\hline
\end{tabular}

Tab. 3: Property Level OLS Regression Model Summary 1996 and 2004 
are within one mile of the 45 brownfield redevelopment sites, whereas only $51 \%$ of the non-hotspots are within the same distance.

However, the regressions at the block group level offered little explanation (low R2) statistically for the variation in house value change between 1996 and 2004. In addition, brownfield-related variables were not found to be as statistically significant as neighbourhood demographics and aggregated physical attributes of the houses. In comparison, property level regressions were able to achieve a much better fit with a significantly higher R2. Understandably, square footage and age of the house entered the model as primary determinants on the list of statistically significant independent variables affecting the property values. Brownfield redevelopment-related independent variables followed in strength of explanatory power. Among different types of redevelopment, "residential" was found to positively impact the property values, whereas "commercial" and "industrial" had negative effects. Interestingly, total redevelopment cost/investment was shown to have an adverse effect. Distance to the closest redeveloped brownfield had a positive effect, as expected. To sum up, smaller-scale redevelopment that led to residential use would bring about the most favourable effects on the surrounding property values.

\subsection{Challenges, Limitations, Lessons}

When looking at both the spatial and statistical analysis results, there are uncertainties. Environmental and geographical processes can have effects on the data. The analytical tools chosen could introduce further uncertainties. When considering the diverse metropolitan area of Milwaukee, it is important to acknowledge that no models will be a truly complete representation of reality, in other words, there will always be missing variables not captured by a seemingly sophisticated model. This is supported by the spatial variation of local R2 results from the GWR runs. An interesting discovery was made during one of the field visits to a brownfield redevelopment site. During the tour of our first site, it was concluded that the brownfield redevelopment site might have been disrupted during redevelopment because it was not flourishing by any means. In fact, the site looked like it had not been touched in many years and was overgrown with weeds. There is the potential that a site like the one toured is similar on paper to another site on the list of 45 redeveloped sites. Similarly captivating findings were made at some seemingly flourishing sites by talking to the locals. For instance, at a commercial redevelopment site, a social worker reflected some insights against the big and nice-looking chain grocery store by pointing out that because of cheaper liquor and unhealthy food sold here, the redevelopment

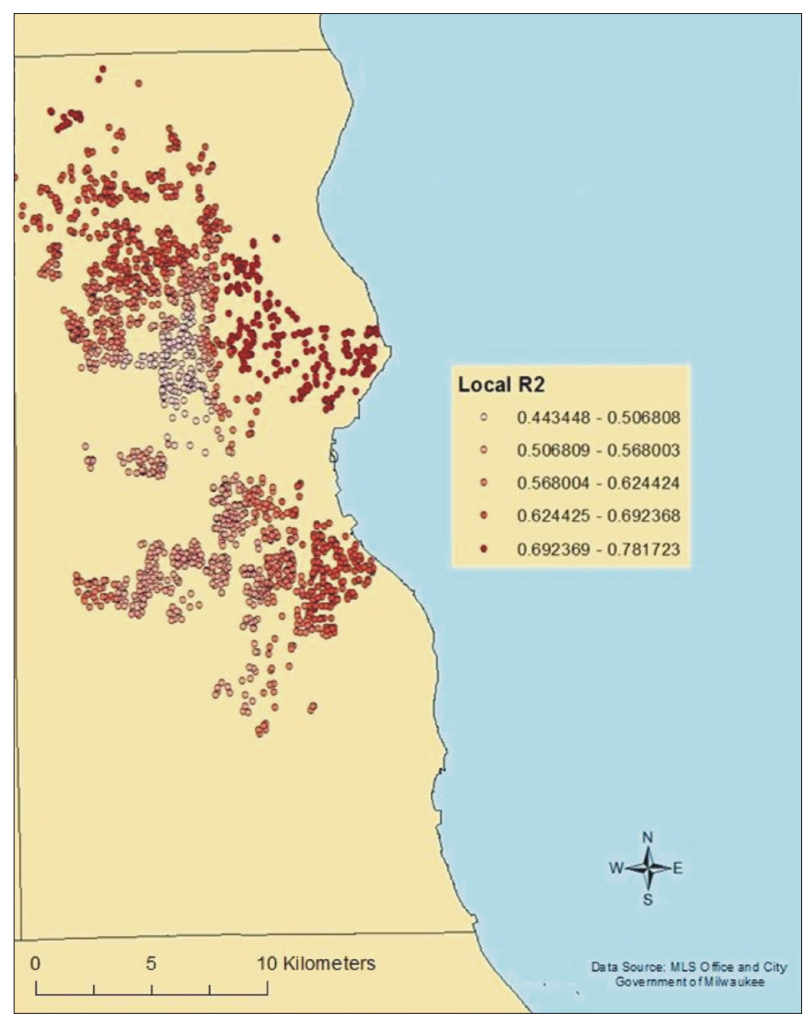

Fig. 7: GWR in 2004 showing local R2

has actually made the existing social problems in the neighbourhood worse and thus contributed to further decay of the community. Again, it is unlikely that deeper social dynamics like this could be picked up by sophisticated models and analyses through a computer. Due to financial means and the scope of this study, only a small number of sites could be visited, but the gain in understanding is well worth the effort.

\subsection{Future Outlook}

The advancement of the brownfield program within the state of Wisconsin and the U.S. is critical to slow down the spread of urban sprawl. With cities growing and populations increasing, it is vital that we use land to its potential and in the most efficient ways possible. This research will assist municipalities, other forms of government, and private investors with more detailed knowledge and operable analytical techniques to evaluate the economic effects that brownfield redevelopment projects generate. Further research is needed to examine environmental and social impacts and eventually determine what equates to ideal locations for brownfield redevelopment along these multiple dimensions.

\section{Acknowledgement}

We would like to thank Carthage College and particularly the SURE (Summer Undergraduate Research Experience) program for funding our research study. 


\section{References:}

AMEKUDZI, A., McNEIL, S., KOUTSOPOULOS, H. N. (2003): Assessing Extrajurisdictional and Areawide Impacts of Clustered Brownfield Developments. Journal of Urban Planning and Development, Vol. 129, No. 1, p. 27.

ARIMAH, B. C., ADINNU, F. I. (1995): Market Segmentation and the Impact of Landfills on Residential Property Values: Empirical Evidence from an African City. Netherlands Journal of Housing and the Built Environment, Vol. 10, No. 2, p. 157-171.

De SOUSA, C. (2005): Policy Performance and Brownfield Redevelopment in Milwaukee, Wisconsin. Professional Geographer, Vol. 57, No. 2, p. 312-327.

De SOUSA, C. A., WU, C., WESTPHAL, L. M. (2009): Assessing the Effect of Publicly Assisted Brownfield Redevelopment on Surrounding Property Values. Economic Development Quarterly, Vol. 23, No. 2, p. 95-110.

ELLERBUSCH, F. (2006): Brownfields: Risk, Property, and Community Value. Local Environment, Vol. 11, No. 5, p. 559-575.

GREENBERG, M. (1998): Understanding the Civic Activities of Residents of Inner City Neighborhoods: Two Case Studies. Urban Geography, Vol. 19, No. 1, p. 68-76.

GREENBERG, M., K. LOWRIE, L. SOLITARE, DUNCAN, L. (2000): Brownfields, Toads, and the Struggle for Neighborhood Redevelopment: A Case Study of the State of New Jersey. Urban Affairs Review, Vol. 35, No. 5, p. 717-733.

GREENBERG, M., SCHNEIDER, D. (1996): Environmentally Devastated Neighborhoods: Perceptions, Realities, and Policies. New Brunswick (NJ): Rutgers University Press, 273 pp.

HILLIER, A. (2010): Invitation to Mapping: How GIS Can Facilitate New Discoveries in Urban and Planning History. Journal of Planning History, Vol. 9, No. 2, p. 122-134.

KAUFMAN, D., CLOUTIER, N. (2006): The Impact of Small Brownfields and Greenspaces on Residential Property Values. Journal of Real Estate Finance and Economics, Vol. 33, No. 1, p. 19-30.

LANGE, D., McNEIL, S. (2004): Clean It and They Will Come? Defining Successful Brownfield Development. Journal of Urban Planning and Development, Vol. 30, No. 2, p. 101-108.

LEGG, R. J., BOWE, T. (2009): Applying Geographically Weighted Regression to a Real Estate Problem, an example from Marquette, Michigan. ArcUser, Vol. 12, No. 2, p. 44-45.

LEJANO, R. P. (2008): Technology and Institutions: A Critical Appraisal of GIS in the Planning Domain. Science, Technology and Human Values, Vol. 33, No. 5, p. 653-678.

NGUYEN, M. T. (2005): Does Affordable Housing Detrimentally Affect Property Values? A Review of the Literature. Journal of Planning Literature, Vol. 20, No. 1, p. 15-26.

RYAN, S. (1999): Property Values and Transportation Facilities: Finding the Transportation-Land Use Connection. Journal of Planning Literature, Vol. 13, No. 4, p. 412-427.

SIMONS, R. (2005): When Bad Things Happen to Good Property. Washington, DC: Environmental Law Institute, 383 pp.

SIMONS, R., SAGINOR, J. (2006): A Meta-Analysis of the Effect of Environmental Contamination and Positive Amenities on Residential Real Estate Values. Journal of Real Estate Research, Vol. 28, No. 1, p. 71-104.

\section{Authors' addresses:}

Assoc. Prof. Wenjie SUN, Ph.D.

Geography and Earth Science, Computer Science, Asian Studies

Carthage College, Postal: 2001 Alford Park Drive, Kenosha, WI 53140, USA

e-mail:wsun@carthage.edu

Brendon JONES

903 Viewpointe Drive, Saint Charles, IL 60174, USA

e-mail: brendon.n.jones@gmail.com

Initial submission 25 October 2012, final acceptance 20 April 2013

Please cite this article as:

SUN, W., JONES, B. (2013): Using multi-scale spatial and statistical analysis to assess the effects of brownfield redevelopment on surrounding residential property values in Milwaukee County, USA. Moravian Geographical Reports, Vol. 21, No. 2, p. 56-64. 